\title{
Factors affecting the atmospheric occurrence and deposition of polychlorinated biphenyls in the Southern Ocean
}

\author{
C. J. Galbán-Malagón ${ }^{1}$, S. Del Vento ${ }^{1,2}$, A. Cabrerizo ${ }^{1, *}$, and J. Dachs ${ }^{1}$ \\ ${ }^{1}$ Department of Environmental Chemistry, IDAEA-CSIC, Jordi Girona 18-26, Barcelona, 08034, Catalunya, Spain \\ ${ }^{2}$ Lancaster Environmental Centre, Lancaster University, Lancaster, LA1 4YQ, UK \\ * present address: Institute for Environment and Sustainability. European Commission, Via Enrico Fermi 2749, \\ 21027, Ispra, Italy
}

Correspondence to: J. Dachs (jordi.dachs@idaea.csic.es)

Received: 25 June 2013 - Published in Atmos. Chem. Phys. Discuss.: 12 July 2013

Revised: 5 November 2013 - Accepted: 8 November 2013 - Published: 12 December 2013

\begin{abstract}
Persistent organic pollutants, such as polychlorinated biphenyls, reach the Southern Ocean atmosphere through long-range atmospheric transport. In this study we report the largest dataset available for the atmospheric occurrence of PCBs in the Southern Ocean surrounding the Antarctic Peninsula from samples obtained during three cruises in 2005, 2008 and 2009. The gas phase concentrations of total PCBs $\left(\Sigma_{25} \mathrm{PCBs}\right)$ ranged from 1 to $70 \mathrm{pg} \mathrm{m}^{-3}$, while the aerosol phase concentrations were significantly lower $\left(0.04\right.$ to $\left.0.4 \mathrm{pg} \mathrm{m}^{-3}\right)$. The aerosol phase is enriched in the more hydrophobic congeners consistent with the model predictions of gas-particle partitioning. There is a net airto-water diffusive flux of PCBs to the Southern Ocean, up to 100 times higher than the dry deposition flux of aerosolbound PCBs. The air-water disequilibrium is higher for the more hydrophobic congeners consistent with the role of the biological pump removing PCBs from the water column by settling of PCBs bound to organic matter. The atmospheric half-lives of PCB 52 and 180 are of 3.8 and 1 days, respectively, as calculated from the measured atmospheric concentration and depositional fluxes. The volatilization of PCBs from Antarctic soils during the austral summer drives higher gas phase concentrations in the atmosphere over Antarctica during the warmer periods. This temperature dependence is not observed for PCBs over the adjacent Southern Ocean, probably due to the importance of long-range atmospheric transport and atmospheric deposition modulating the atmospheric occurrence of PCBs.
\end{abstract}

\section{Introduction}

Polychlorinated biphenyls (PCBs) are distributed in the global atmosphere (Gioia et al., 2008, 2012; Bogdal et al., 2012) due to their persistence, semivolatility, and potential for long-range atmospheric transport. In addition, their low degradability, toxicity, and ability to bioacumulate/biomagnify along food chains raise concern on their impact on ecosystem health (Jones and De Voogt, 1999). Its introduction into the environment is the result of their use for decades, mainly in the Northern Hemisphere (Breivik et al., 2004). The Stockholm Convention on Persistent Organic Pollutants (POPs) approved in 2001 bans the use, production and export of several families of POPs, including PCBs (chm.pop.int).

PCBs are considered as a surrogate for the behaviour of hydrophobic organic contaminants as PCBs comprise congeners with a wide range of physical chemical properties. The fate, transport and sinks of PCBs in different global regions and environments have received considerable attention during the last decades (see for example Lohmann et al., 2007). The occurrence of PCBs have also been reported in remote regions such as Antarctica and the Southern Ocean atmosphere (Tanabe et al., 1983; Iwata et al., 1993; Kallenborn et al., 1998; Fuoco et al., 1996; Montone et al., 2003, 2005; Gambaro et al., 2005), seawater (Tanabe et al., 1983; Galbán-Malagón et al., 2013), soils (Cabrerizo et al., 2012; Kang et al., 2012) and biota (Larsson et al., 1992; BengtsonNash et al., 2008; Galbán-Malagón et al., 2013a; Cabrerizo et al., 2012; Zhang et al., 2013; Brault et al., 2013). The 
atmospheric long-range transport of PCBs occurs through successive steps of volatilization and deposition (hops) and PCBs can reach eventually Polar Regions like the Arctic and Antarctica (Wania and Mackay, 1996; Jurado and Dachs, 2008). This process is known as "grasshopping" and POPs with physical-chemical properties like those of PCBs are known as hoppers (Wania and Mackay, 1996; Lohmann et al., 2007). Therefore, the quantification of atmospheric deposition and volatilization processes is important to understand and predict the long-range atmospheric transport of POPs and their impact to remote regions.

The low temperatures in Polar Regions favour partitioning of organic pollutants to soils, vegetation and seawater through "cold trapping" (Wania and Mackay, 1996). However, this process is not irreversible, and re-volatilization as the consequence of declining levels in the atmosphere due to lower primary emissions, or climate change, can occur in Polar Regions (Ma et al., 2011; Cabrerizo et al., 2013). In addition, the Southern Ocean is characterised by high primary productivity and biomass during the austral summer (Tréguer and Jacques, 1998; Boyd, 1995), driving high settling fluxes of organic matter and organic matter-bound hydrophobic pollutants to deep waters, and enhancing the atmospheric deposition of POPs such as PCBs by a process known as biological pump (Dachs et al., 2002; Jurado and Dachs, 2008). The influence of the biological pump on air-water diffusive fluxes of PCBs has been assessed in lakes (Dachs et al., 1999, 2000; Meijer et al., 2006; Nizzetto et al., 2012), the Mediterranean Sea (Berrojalbiz et al., 2011), and the Arctic Ocean (GalbánMalagón et al., 2012). A recent companion study has shown that the biological pump can also affect the levels of PCBs in the Southern Ocean water column (Galbán-Malagón et al., 2013), but its influence on the PCB occurrence in the Southern Ocean atmosphere is still limited to estimates from environmental models (Dachs et al., 2002; Jurado and Dachs, 2008).

Previous reports on PCBs concentrations in the Antarctic and the Southern Ocean atmosphere are scarce compared to the Arctic and its surrounding oceans (Bengtson-Nash, 2011). These studies pointed out that the atmospheric concentrations in Antarctica are influenced by meteorological conditions, like temperature (Ockenden et al., 2001) and by the synoptic atmospheric circulation in the Antarctic region (Montone et al., 2003). Also, the direct transport of PCBs from South America was evidenced by temporal series at Signy island (Kallenborn et al., 1998). However, the previous studies on the atmospheric occurrence of PCBs in Antarctica covered small geographic areas and most were restricted to sites near Antarctic scientific bases (Larsson et al., 1992; Kallenborn et al., 1998; Ockenden et al., 2001; Gambaro et al., 2005; Baek et al., 2011; Li et al., 2012; Cabrerizo et al., 2013; Kallenborn et al., 2013). In the present study, we report the atmospheric gas and aerosol phase PCBs occurrence from samples taken during three Antarctic cruises (2005, 2008 and 2009) covering a large region including the Bransfield Strait and the Weddell, Bellingshausen and South Scotia Seas. In addition, a terrestrial campaign was carried out, simultaneously to the 2009 cruise, at Livingston Island in which PCBs were measured in the gas and aerosol phase over land. Therefore, the objectives are (i) to report the largest dataset available of PCB concentrations in the Southern Ocean atmosphere, and (ii) assess the different factors driving the occurrence of PCBs, such as long-range atmospheric transport, volatilization from Antarctic snow and soils, and atmospheric deposition to seawater.

\section{Materials and methods}

\subsection{Sampling}

The atmospheric samples (gas and aerosol phase) were collected on board the R/V Hespérides during three Antarctic surveys around the Antarctic peninsula (ICEPOS, February 2005 and ATOS II, January-February 2009), and in the South Scotia Sea (ESSASI, January 2008). In addition, a terrestrial sampling campaign was carried out in January-February 2009 at Livingston island (Southern Shetlands, Antarctica) where atmospheric samples (gas and aerosol phase) were collected at two sites. The air samples were collected using a high-volume air sampler (MCV: CAV-A/HF, Collbató, Spain). The sampling sites were Polish beach $(13 \mathrm{~m}$ of altitude), located near the coast and covered with bare soil, and Pico Radio hill (131 m of altitude) covered by soil with lichens. Atmospheric conditions during the sampling periods were obtained from the meteorological stations deployed on board the ship and at Livingston Island. Details of sampling events, locations and ancillary data for each sample are given in Figs. S1 and S2, and Table S1 in Annex I of Supplement. The sampling methodology has been described previously (Galbán-Malagón et al., 2012; Cabrerizo et al., 2013). For the sampling of oceanic air, the high-volume sampler was deployed over the vessel bridge connected to a wind direction sensor in order to avoid contamination from the ship. Sampling flow rate was set at $40 \mathrm{~m}^{3} \mathrm{~h}^{-1}$ and the sampling volumes averaged $600 \mathrm{~m}^{3}, 1000 \mathrm{~m}^{3}$ and $1400 \mathrm{~m}^{3}$ for the gas phase samples of the ICEPOS, ESSASI and ATOS II cruises, respectively, and $800 \mathrm{~m}^{3}$ for the samples taken at Livingston Island. During the ATOS II cruise, a second highvolume air sampler was operated in parallel for the sampling of aerosol phase only, with longer sampling periods, so higher volumes of air were sampled (around $1800 \mathrm{~m}^{3}$ ). The gas phase was collected on a polyurethane foam (PUF) plugs $(100 \mathrm{~mm}$ diameter $\times 100 \mathrm{~mm}$, Klaus Ziemer $\mathrm{GmbH}$, Germany) and the aerosol phase was filtered on a quartz microfiber filters $(203 \times 254 \mathrm{~mm}$, QMA, Whatman, England).

Previous to the sampling campaigns, PUFs were cleaned in the laboratory by Soxhlet extraction with acetone : hexane $(3: 1)$, dried under vacuum, packed in aluminium foil envelopes and introduced into two zip-sealed bags until 
sampling. The QMA filters were placed inside aluminium foil envelopes and were combusted for $6 \mathrm{~h}$ at $450^{\circ} \mathrm{C}$. After combustion, filters were kept inside two zip-sealed bags until sampling. After sampling, the PUFs and QMA filters were packed similarly and kept at $4{ }^{\circ} \mathrm{C}$ and $-20^{\circ} \mathrm{C}$, respectively, until their analysis in the laboratory.

\subsection{Chemical analysis}

Briefly, all gas phase samples collected on PUFs were Soxhlet extracted for $24 \mathrm{~h}$ using acetone: hexane $(3: 1 v / v)$, while QMA filters were extracted using methanol : dichloromethane $(1: 2 v / v)$. Prior to extraction, samples were spiked with PCB 65 and PCB 200 (Dr Ehrenstorfer, GmbH, Germany), which were used as recovery standards. Extracts were reduced in a rotary evaporation unit (R-200, Büchi, Italy) until $0.5 \mathrm{~mL}$, and fractionated on a $3 \%$ deactivated alumina column $(3 \mathrm{~g})$ with $1 \mathrm{~g}$ of anhydrous sodium sulphate on top. The first fraction containing PCBs was collected using $12 \mathrm{~mL}$ of hexane, a second fraction containing other compounds was collected using $15 \mathrm{~mL}$ of hexane: dichloromethane $(1: 2 v / v)$. All fractions were concentrated until $1 \mathrm{~mL}$ by rotary evaporation and solvent exchange to isooctane under a purified $\mathrm{N}_{2}$ stream until a final volume of $150 \mu \mathrm{L}$. Identification and quantification was done using the retention time of individual PCB congeners. The details of the methodology used for analysing the samples taken at Livingston island has been described elsewhere (Cabrerizo et al., 2013).

PCBs were analysed by a gas chromatograph coupled to a $\mu$-ECD detector (Agilent Technologies, model 7890), provided with a HP-5MS $60 \mathrm{~m}$ capillary column (inner diameter $0.325 \mu \mathrm{m}$, film thickness $0.25 \mu \mathrm{m}$ ). The instrument was operated in splitless mode (close for $1.5 \mathrm{~min}$ ). The oven programmed temperature started from $90^{\circ} \mathrm{C}$ (hold for $1 \mathrm{~min}$ ) to $190^{\circ} \mathrm{C}$ at $20^{\circ} \mathrm{C} \mathrm{min}^{-1}$, and then to $310^{\circ} \mathrm{C}\left(3^{\circ} \mathrm{C} \mathrm{min}^{-1}\right)$ (holding time $18 \mathrm{~min}$ ). Injector and detector temperatures were 280 and $320^{\circ} \mathrm{C}$, respectively. Helium and nitrogen were used as carrier $\left(1.5 \mathrm{~mL} \mathrm{~min}^{-1}\right)$ and makeup $\left(60 \mathrm{~mL} \mathrm{~min}^{-1}\right)$ gases respectively. Prior to injection, $5 \mathrm{ng}$ of PCB 30 and PCB 142 were added as internal standards to all samples. The analysed congeners were PCB 18, 17, 31, 28, 33, 52, 49, $99+101,110,151,149,118,153,132+105,138,158,187$, $183,128,177,171,156$ and 180. Organic and elemental carbon in the aerosol phase was determined using the thermaloptical transmittance in a Sunset Laboratory Carbon Analyser using the NIOSH temperature protocol (Birch and Cary, 1996).

\subsection{Quality control and quality assurance}

One blank was collected every five field samples and followed the same extraction process than samples. During quantification, the chromatographic blank signal was subtracted from the sample's signal. Blank levels were always below $5 \%$ of sample values. The range of recoveries for PCBs 65 and 200 for the gas phase samples were 51-75\% and 51-81 for the ICEPOS cruise, 53-78\% and 57-87\% for the ESSASI cruise, and $67-76 \%$ and $51-81 \%$ for the ATOS II cruise. The recoveries for samples taken at Livingston Island were $53-76 \%$ and $58-101 \%$ for PCB 65 and 200, respectively. The recoveries for the aerosol phase samples were in the range $52-78 \%$ and $69-115 \%$ for PCB 65 and 200, respectively (Table S2 in Annex II). Instrumental detection limits (IDLs) were calculated using the least concentrated quantifiable standard divided by the averaged volume of samples. IDLs ranged from 0.001 to $0.023 \mathrm{pg} \mathrm{m}^{-3}$. Limits of detection and quantification (LODs and LOQs) were from 0.006 to $0.85 \mathrm{pg}$ on column, and from 0.019 to $2.83 \mathrm{pg}$ on column, respectively. More information about the IDLs, LOQs and LODs is given on Table S3 in Annex II.

\subsection{Atmospheric back trajectories}

The air mass back trajectories were retrieved from the NOAA HYSPLIT model to study the source region of the atmospheric samples (Draxler and Rolph, 2011). Three $24 \mathrm{~h}$ back trajectories were calculated for each sample corresponding to the initial, middle and final sampling time. Back trajectories were estimated for each sampling period at $25 \mathrm{~m}$ height, an example of the dominant source back trajectories is given in Fig. S3 in ANNEX III.

\subsection{Estimation of aerosol-gas partitioning and atmospheric deposition fluxes}

A common approach to predict the aerosol-gas partition coefficients is (Finizio et al., 1998),

$K_{\mathrm{P}}=\frac{C_{\mathrm{A}}}{C_{\mathrm{G}} \mathrm{TSP}}=1.8 \times 10^{-12} f_{\mathrm{OC}}\left(\frac{\gamma_{\mathrm{Oct}} \mathrm{MW}_{\mathrm{OCT}}}{\gamma_{\mathrm{OM}} \mathrm{MW}_{\mathrm{OM}}}\right) K_{\mathrm{OA}}$

where $C_{\mathrm{A}}$ and $C_{\mathrm{G}}$ are the aerosol and gas phase concentrations $\left(\mathrm{pg} \mathrm{m}^{-3}\right)$ of PCB congeners, TSP is the concentration of total suspended particles $\left(\mu \mathrm{g} \mathrm{m}^{-3}\right), f_{\mathrm{OC}}$ is the fraction of organic carbon in the aerosol, $\gamma_{\mathrm{Oct}}$ and $\gamma_{\mathrm{OM}}$ are the activity coefficients of PCBs in octanol and the aerosol organic matter, $\mathrm{MW}_{\text {Oct }}\left(\mathrm{g} \mathrm{mol}^{-1}\right)$ and $\mathrm{MW}_{\mathrm{OM}}\left(\mathrm{g} \mathrm{mol}^{-1}\right)$ are the molecular weight of octanol and aerosol organic matter, and $K_{\mathrm{OA}}$ is the temperature corrected octanol-air partition coefficient (Harner and Bidleman, 1998a).

The PCB fugacity in air $\left(f_{\mathrm{A}}, \mathrm{Pa}\right)$ and water $\left(f_{\mathrm{W}}, \mathrm{Pa}\right)$ are given by

$\begin{aligned} f_{\mathrm{A}} & =\frac{10^{-12} C_{\mathrm{G}} R T}{\mathrm{MW}} \\ f_{\mathrm{W}} & =\frac{10^{-12} C_{\mathrm{TD}} H^{\prime} R T_{\mathrm{W}}}{\mathrm{MW}}\end{aligned}$

where $C_{\mathrm{TD}}\left(\mathrm{pg} \mathrm{m}^{-3}\right)$ is the truly dissolved-phase concentration in seawater, which has been obtained by correcting the 
apparent dissolved phase concentrations measured during the ESSASSI and ATOS-II campaigns (Galbán-Malagón, et al., 2013), using the dissolved organic carbon (DOC) as a surrogate for the colloidal phase as commonly done (Nizzeto et al., 2011; Rowe et al., 2007; Totten et al., 2001; GarcíaFlor et al., 2005). Values of $C_{\mathrm{TD}}$ are given in Fig. $2 \mathrm{c}$ and Table S11, while the discussion of these concentrations has been given in a companion paper (Galbán-Malagón et al., 2013). $H^{\prime}$ is the dimensionless Henry's Law Constant corrected for temperature and salinity (Table S10 in Annex V), $R$ is the ideal gas constant $\left(8.314 \mathrm{~Pa} \mathrm{~mol}^{-1} \mathrm{~K}^{-1}\right), T_{\mathrm{W}}(K)$ is the surface water temperature, and $\mathrm{MW}\left(\mathrm{g} \mathrm{mol}^{-1}\right)$ is the molecular weight of the studied compound. The uncertainties associated to the fugacity ratio are derived from uncertainties on $C_{\mathrm{G}}, C_{\mathrm{TD}}$ and $H^{\prime}$ (Bruhn et al., 2003). Uncertainties associated to measured gas and dissolved phase were estimated to be of $15 \%$. The uncertainty on the Henry's Law Constant is especially relevant (Bruhn et al., 2003): a $30 \%$ uncertainty on $H^{\prime}$ has been assumed in this study (Li et al., 2003). Therefore, the logarithm of $f_{\mathrm{W}} f_{\mathrm{A}}^{-1}$ ranging from -0.11 to 0.5 indicates that the compounds are close to air-water equilibrium, fugacity ratios below -0.11 indicate that the direction of the exchange between air and water is a net deposition, and over 0.5 indicates a net volatilization.

The air-water net diffusive fluxes $\left(F_{\mathrm{AW}}, \mathrm{ng} \mathrm{m}^{-2} \mathrm{~d}^{-1}\right)$ were estimated for the oceanic samples using the two-film model as follows,

$$
F_{\mathrm{AW}}=k_{\mathrm{AW}}\left(C_{\mathrm{TD}}-\frac{C_{\mathrm{G}}}{H^{\prime}}\right)
$$

where $k_{\mathrm{AW}}\left(\mathrm{m} \mathrm{d}^{-1}\right)$ is the air-water mass transfer velocity that depends on the compound's physical-chemical properties, wind speed and $T_{\mathrm{W}}$ (Dachs et al., 2002; Jurado et al., 2004).

Atmospheric dry deposition was estimated by:

$F_{\mathrm{DD}}=-v_{\mathrm{D}} C_{\mathrm{A}}$

where $v_{\mathrm{D}}$ is the aerosol deposition velocity, which for the Antarctic atmosphere a value of $258 \mathrm{~m} \mathrm{~d}^{-1}$ has been reported (Grönlund et al., 2002).

\section{Results and discussion}

\subsection{Occurrence of PCBs in the Southern Ocean atmosphere}

Concentrations of $\Sigma_{25} \mathrm{PCBs}$ in the gas and aerosol phase are depicted in Fig. 1a and b, respectively. Figure 2a and b shows the average profiles of PCB congeners in the aerosol and gas phase samples, respectively, and the congener specific concentrations for each sampling event are given in Tables S4S9 in Annex IV. Gas phase concentrations of $\Sigma_{25}$ PCBs ranged from 7.1 to $45.2 \mathrm{pg} \mathrm{m}^{-3}, 6.2$ to $78.9 \mathrm{pg} \mathrm{m}^{-3}$, and
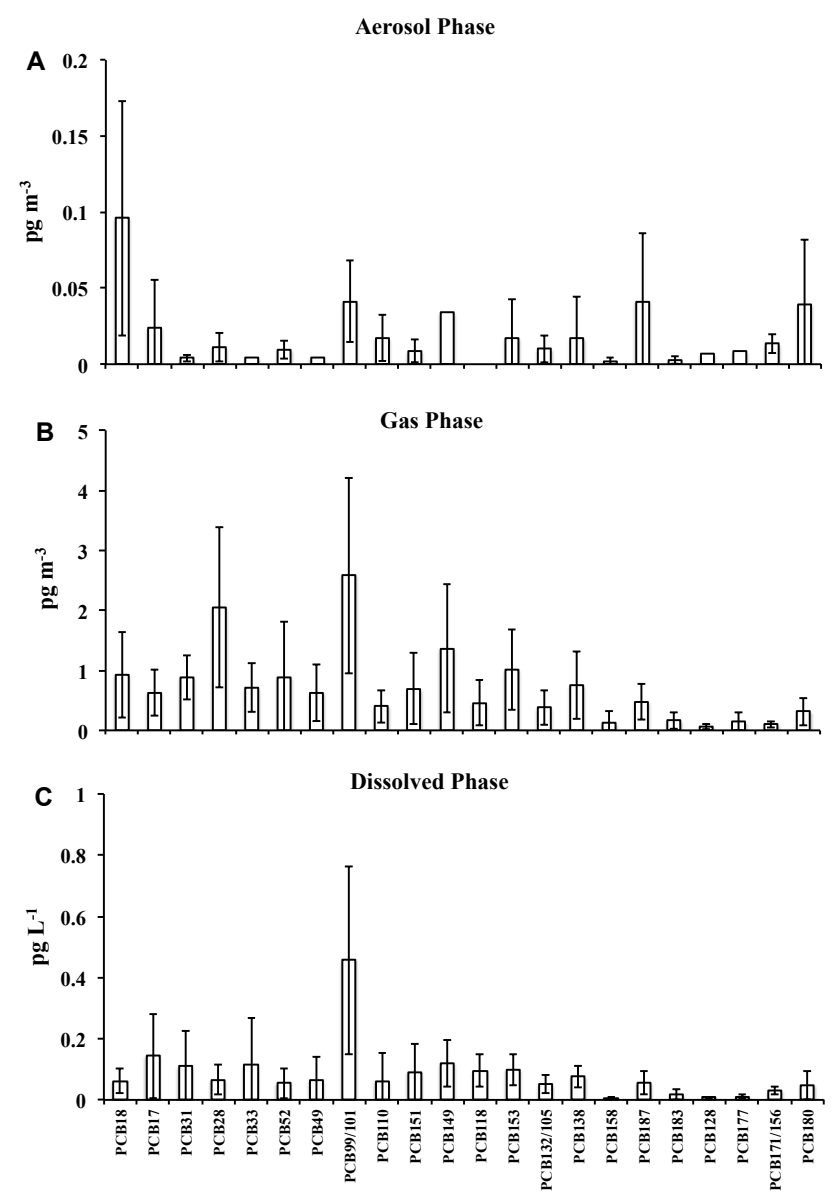

Fig. 1. Congener specific occurrence of PCBs. Average profiles of PCB congeners in the aerosol $\left(\mathbf{A}, \mathrm{pg} \mathrm{m}^{-3}\right), \operatorname{gas}\left(\mathbf{B}, \mathrm{pg} \mathrm{m}^{-3}\right)$ and dissolved phase $\left(\mathbf{C}, \mathrm{pg} \mathrm{L}^{-1}\right)$ in the Southern Ocean. Dissolved phase concentrations are taken from Galbán-Malagón et al. (2013a).

5.2 to $39.9 \mathrm{pg} \mathrm{m}^{-3}$ for the ICEPOS, ESSASSI and ATOSII cruises, respectively. The gas phase concentrations at Livingston Island ranged from 2.1 to $3.1 \mathrm{pg} \mathrm{m}^{-3}$, and from 4 to $29 \mathrm{pg} \mathrm{m}^{-3}$ at Polish Beach and Pico Radio Hill, respectively. The contribution of the seven ICES congeners to the $\Sigma_{25}$ PCBs concentrations averaged $52 \%, 51.7 \%$ and $50.5 \%$ and $45.7 \%$ for the ICEPOS, ESSASI, ATOS II and Livingston Island samples, respectively. A Kruskall-Wallis test revealed that the median values of the samples were different among the different cruises $(p<0.01)$. A post hoc Dunn's test showed that $\Sigma_{25} \mathrm{PCBs}$ at Polish beach were significantly lower $(p<0.05)$ than the concentrations measured in the South Scotia Sea atmosphere, but not significantly different than the concentrations in the other campaigns (Fig. S4 in Annex IV).

These gas phase $\Sigma_{25} \mathrm{PCB}$ concentrations are lower than those reported in the early 1980s $\left(180 \mathrm{pg} \mathrm{m}^{-3}\right)$ for the Southern Indian and Pacific Oceans (Tanabe et al., 1983), comparable to those reported in other regions of the Southern 
Ocean and Antarctic continent (Larsson et al., 1992; Iwata et al., 1993; Kallenborn et al., 1998; Montone et al., 2003, 2005; Gambaro et al., 2005; Baek et al., 2011; Li et al., 2012; Cabrerizo et al., 2013) and higher than concentrations reported at Dronning Maud Land (Kallenborn et al., 2013). However, the number of congeners is not the same for the different studies, and since we report the concentrations for a higher number of congeners (see Table 1), atmospheric PCBs concentrations may have decreased during recent decades. However, the comparison of concentrations of individual congeners does not show a significant trend due to the large variability in concentrations in some of the earlier studies. Since atmospheric PCB concentrations have decreased in source regions, and in Southern Ocean seawater (Galbán-Malagón et al., 2013), it is likely that a decrease of atmospheric PCB concentrations have also decreased during the last two decades in the Antarctic Peninsula atmosphere. The predominant compounds in the gas phase in this study were the more volatile compounds (i.e. 28, 52, 99/101) which agrees with the most recent published results in other Antarctic regions (Baek et al., 2011; Li et al., 2012; Cabrerizo et al., 2013; Kallenborn et al., 2013).

Only four and ten of the aerosol phase samples taken during the ATOS II cruise and at Livingston Island, respectively, had levels of PCBs above LOQ (see Fig. 1b, and Table S8 in Annex IV). Aerosol phase concentration ranges for $\Sigma_{25} \mathrm{PCBs}$ were 0.2 to $0.7 \mathrm{pg} \mathrm{m}^{-3}$ during the ATOS II cruise, and 0.06 to $0.4 \mathrm{pg} \mathrm{m}^{-3}$ and 0.04 to $0.07 \mathrm{pg} \mathrm{m}^{-3}$ at Pico Radio hill and Polish beach in sites from Livingston Island, respectively. There were no significant differences among the aerosol phase $\Sigma_{25}$ PCBs concentrations over the Southern Ocean and those in the Livingston island atmosphere (Kruskall-Wallis test). Aerosol phase concentrations accounted for 1 to $4 \%$ of the total atmospheric (gas + aerosol) burden. This is the first time that PCBs concentrations in the aerosol phase are reported for Antarctica and the Southern Ocean. These concentrations are significantly lower (Kruskal-Wallis $p<0.05$ ) than the aerosol phase PCB concentrations reported for other oceanic regions like the North Atlantic and Arctic Ocean (Galbán-Malagón et al., 2012). The pattern of PCB congeners in the aerosol phase has a higher contribution of the more chlorinated congeners in comparison to the gas phase (Fig. 2).

\subsection{Gas-particle partitioning of PCBs}

The understanding and quantification of gas-particle partitioning is important to predict and assess the atmospheric deposition, atmospheric degradation/transformation processes, and the long-range atmospheric transport of PCBs in the environment (Bidleman, 1988; Scheringer, 1997). Since this is the first report of aerosol phase concentrations in the Southern Ocean atmosphere, it is useful to evaluate the gas-particle partitioning of PCBs in this remote atmosphere in order to compare it with model predictions.
Measured $K_{\mathrm{P}}$ was calculated using the measured $C_{\mathrm{A}}, C_{\mathrm{G}}$, and TSP values for the Southern Ocean and Livingston Island atmosphere (Fig. 3). These values can be compared with the predicted $K_{\mathrm{P}}$ obtained from the right side term of Eq. (1) assuming that the ratio $\gamma_{\mathrm{Oct}} \mathrm{MW}_{\text {Oct }} / \gamma_{\mathrm{OM}} \mathrm{MW}_{\mathrm{OM}}$ equals the unity (Finizio et al., 1997), an assumption that does not affect the discussion below. $f_{\mathrm{OC}}$ was measured in the aerosols taken at Livingston island and it ranged from below detection limit to $0.31 \mu \mathrm{g} \mathrm{m}^{-3}$. The average was $0.28 \mu \mathrm{g} \mathrm{m}^{-3}$ for all samples above LOQ. Measured and predicted $K_{\mathrm{P}}$ (see Eq. 1) for each sampling period are shown in Tables S15-S17 in Annex V.

Measured and predicted $K_{\mathrm{P}}$ are significantly correlated in the four sampling periods for which the aerosol phase concentrations over the Southern Ocean are available (Fig. 3, upper panels), and for the pairs of aerosol and gas phase concentrations taken at the coastal site of Polish Beach at Livingston Island (Fig. 3, lower panels). Conversely, at Pico Radio hill, which is a site further in-land, the measured $K_{\mathrm{P}}$ did not correlate with the predicted $K_{\mathrm{P}}$ (Fig. S10 in Annex $\mathrm{V})$. The slopes of the correlation between measured and predicted $K_{\mathrm{P}}$ were always significantly lower than unity (Fig. 3), similar to those reported in continental environments (Mandalakis and Stephanou, 2007; Radonić et al., 2011), but lower than the slopes reported for PCBs in urban atmospheres (Harner and Bidleman, 1998b). The low slopes observed over the ocean and coastal sites can be due to various factors. First, $\gamma_{\mathrm{OM}}$ can be different for the different PCB congeners inducing a slope lower than unity when measured $K_{\mathrm{P}}$ is regressed against predicted $K_{\mathrm{P}}$ (see Eq. 1). Another possibility is that PCBs in the gas and aerosol phase are not in equilibrium. This lack of equilibrium can be driven by recent emissions and losses of PCBs to the atmosphere. At the Polish beach and Pico Radio Hill sites there was a net volatilization of PCB from soils as reported in a companion work (Cabrerizo et al., 2013). The lack of correlation between predicted and measured $K_{\mathrm{P}}$ at Pico Radio hill would be due to the fresh inputs of PCBs from soil, which have had no time to equilibrate with the aerosol phase. Conversely, the atmosphere at the coastal site is more influenced by the ocean, and while there is a volatilization of PCBs from soils at Polish beach, over the adjacent seawaters there is a net deposition to close to air-water equilibrium (see below). Indeed, the occurrence of PCBs in the aerosol and gas phase is the result of the interplay of various factors such as volatilization from local secondary sources, long-range atmospheric transport, and deposition.

The predicted $K_{\mathrm{P}}$ are higher than the measured $K_{\mathrm{P}}$ for the more hydrophobic congeners (Fig. 3), but this comparison is due to the assumption that $\gamma_{\mathrm{Oct}} \mathrm{MW}_{\mathrm{Oct}} / \gamma_{\mathrm{OM}} \mathrm{MW}_{\mathrm{OM}}$ equals unity. It is likely that $\gamma_{\mathrm{OM}} \mathrm{MW}_{\mathrm{OM}}$ is higher than $\gamma_{\mathrm{Oct}}$ $\mathrm{MW}_{\text {Oct }}$, which would lead to similar values of predicted and measured $K_{\mathrm{P}}$ for the high chlorinated congeners. However, in order that models can predict the measured $K_{\mathrm{P}}$ values for congeners of different chlorination, it would be needed that 
Table 1. Comparison of the gas phase PCBs concentrations $\left(\mathrm{pg} \mathrm{m}^{-3}\right)$ reported in the literature for the Antarctic atmosphere with those reported in this study.

\begin{tabular}{|c|c|c|c|c|}
\hline \multirow[t]{2}{*}{ Location } & \multicolumn{4}{|c|}{$\Sigma \mathrm{PCBs}$} \\
\hline & Year & Mean & SD & Reference \\
\hline Sabrina Coast & 1981 & 180 & & Tanabe et al. $(1983)^{\mathrm{a}}$ \\
\hline Balleny Islands & 1981 & 64 & & Tanabe et al. $(1983)^{\mathrm{a}}$ \\
\hline Syowa Station & 1982 & 81 & & Tanabe et al. $(1983)^{\mathrm{a}}$ \\
\hline Amundsen Bay & 1982 & 96 & & Tanabe et al. $(1983)^{\mathrm{a}}$ \\
\hline \multirow[t]{2}{*}{ Cape Evans (Ross Island) } & 1989 & 32.33 & 34.02 & Larsson et al. $(1992)^{b}$ \\
\hline & 1990 & 6.00 & & Larsson et al. $(1992)^{\mathrm{b}}$ \\
\hline Southern Ocean (Daisan-Nisin Maru Cruise) & 1990 & 28.00 & & Iwata et al. $(1993)^{\mathrm{c}}$ \\
\hline Signy Island & 1995 & 67.28 & 41.28 & Kallenborn et al. $(1998)^{\mathrm{d}}$ \\
\hline King George Island & 1996 & 35.33 & 27.01 & Montone et al. $(2003)^{\mathrm{e}}$ \\
\hline Transect Brazil-Antarctica & 1995 & 62.43 & 8.89 & Montone et al. $(2005)^{\mathrm{e}}$ \\
\hline Halley Land Base & 1998 & 2.78 & & Oeckenden et al. $(2001)^{\mathrm{f}}$ \\
\hline Weddell Sea & 1998 & 42.66 & & Oeckenden et al. $(2001)^{\mathrm{f}}$ \\
\hline Terra Nova Bay & 2004 & 1.58 & & Gambaro et al. $(2005)^{\mathrm{g}}$ \\
\hline \multirow[t]{2}{*}{ King George Island } & 2005 & 18.70 & 10.59 & Baek et al. $(2011)^{\mathrm{h}}$ \\
\hline & 2006 & 20.83 & 10.07 & Baek et al. $(2011)^{\mathrm{h}}$ \\
\hline King George Island (Great Wall Station) & 2009-2010 & 4.45 & 2.36 & Li et al. $(2012)^{\mathrm{i}}$ \\
\hline Dronning Maud Land & $2008-2010$ & 1.49 & 1.00 & Kallenborn et al. $(2013)^{\mathrm{j}}$ \\
\hline Livingston Island (Radio Hill and Sofia Mt) & 2009 & 9.15 & 3.61 & Cabrerizo et al. $(2013)^{\mathrm{k}}$ \\
\hline Bellingshausen & 2005 & 25.82 & 13.16 & This Study \\
\hline Weddell & 2005 & 16.93 & 16.43 & This Study \\
\hline Bransfield & 2005 & 20.97 & 3.73 & This Study \\
\hline South Scotia Sea & 2008 & 45.84 & 29.91 & This Study \\
\hline Bellingshausen & 2009 & 20.89 & 16.59 & This Study \\
\hline Bransfield & 2009 & 13.38 & 7.61 & This Study \\
\hline Weddell & 2009 & 13.49 & 5.06 & This Study \\
\hline
\end{tabular}

\footnotetext{
a Sum of unspecified PCBs congeners.

b Sum of PCBs $95,101,110,149,153$ and 138

${ }^{c}$ Sum of PCBs 8, 15, 16, 17, 18, 20, 28, 31, 32, 33, 34, 37, 41, 42, 44, 49, 51, 52, 53, 58, 60, 66, 69, 70, 74, 87, 91, 95, 101,118, 128, 138, 144 and 149.

d Sum of PCBs 18, 28, 31, 47, 52, 66, 74, 99, 101, 105, 114, 118, 128, 138, 149, 153, 156, 167, 170, 180, 187 and 189.

e Sum of PCBs 18, 52, 44, 101, 118, 153,138, 187, 128 and 180.

${ }^{\mathrm{f}}$ Sum of PCBs 28, 52, 101, 153, 132, 138 and 180 .

g Sum of PCBs $1,2,3,4+10,9+7,6,8,5,12,15,19,18,17,24+27,16+32,29,26,25,28+31,33+20,22,46+69,62,49,47+48$, $44+59,42,71,67,63,74,70,66,56+60,77,93+95,91,92,84+90 / 101,119,83,97,123+107 / 109,118,136,151,135+144,149$ 134, 146, 141, 137, 164, 167, 179, 176, 178, 185, 174, 177, 197 and 194.

$\mathrm{h}$ Sum of all the PCBs except PCB 11.

${ }^{\mathrm{i}}$ Sum of PCBs 28, 52, 77, 81, 101, 105, 114, 123, 126, 128, 138, 153, 156, 157, 167, 169, 180, 189 and 209.

j Sum of PCBs: gas + aerosol 28, 31, 33, 37, 47, 52, 66, 74, 99, 101, 105, 114.

${ }^{\mathrm{k}}$ Sum of PCBs $18,17,31,28,33,52,49,44,74,70,95,99+101,87,118,110,151,149,153,132+105,138,158,128,169,187,183$, $177,171+156,180,191,170,201 / 199,195,194,205,206,208$ and 209
}

$\gamma_{\mathrm{OM}}$ varies for different congeners, something that cannot be evaluated in this work.

\subsection{Air-water diffusive exchange and dry deposition of PCBs}

Diffusive air-water exchange is the dominant process for the transfer of PCBs from the atmosphere to seawater (Jurado et al., 2004). The air-water fugacity ratios $\left(f_{\mathrm{W}} f_{\mathrm{A}}^{-1}\right)$ describe the direction of the net diffusive flux. The calculated water-air fugacity ratios showed that deposition dominates over volatilization for most compounds and sampling periods
(Fig. 4a), and thus there was a net absorption of PCBs during the ESSASI (South Scotia Sea) and ATOS II (Weddell, Bransfield and Bellingshausen seas) cruises (Fig. 4a, and Table S12 in Annex V). At the seawater adjacent to the coastal Polish Beach site, air and water were close to equilibrium conditions.

The low PCB levels in seawater, driving the air-water disequilibrium, are the consequence of two factors (i) the isolation of Antarctic water masses (Rintoul, 2000; BengtsonNash et al., 2010) from oceanic waters at northern latitudes which have higher concentrations (Nizzetto et al., 2010), and (ii) the action of the biological pump that actively sequesters 

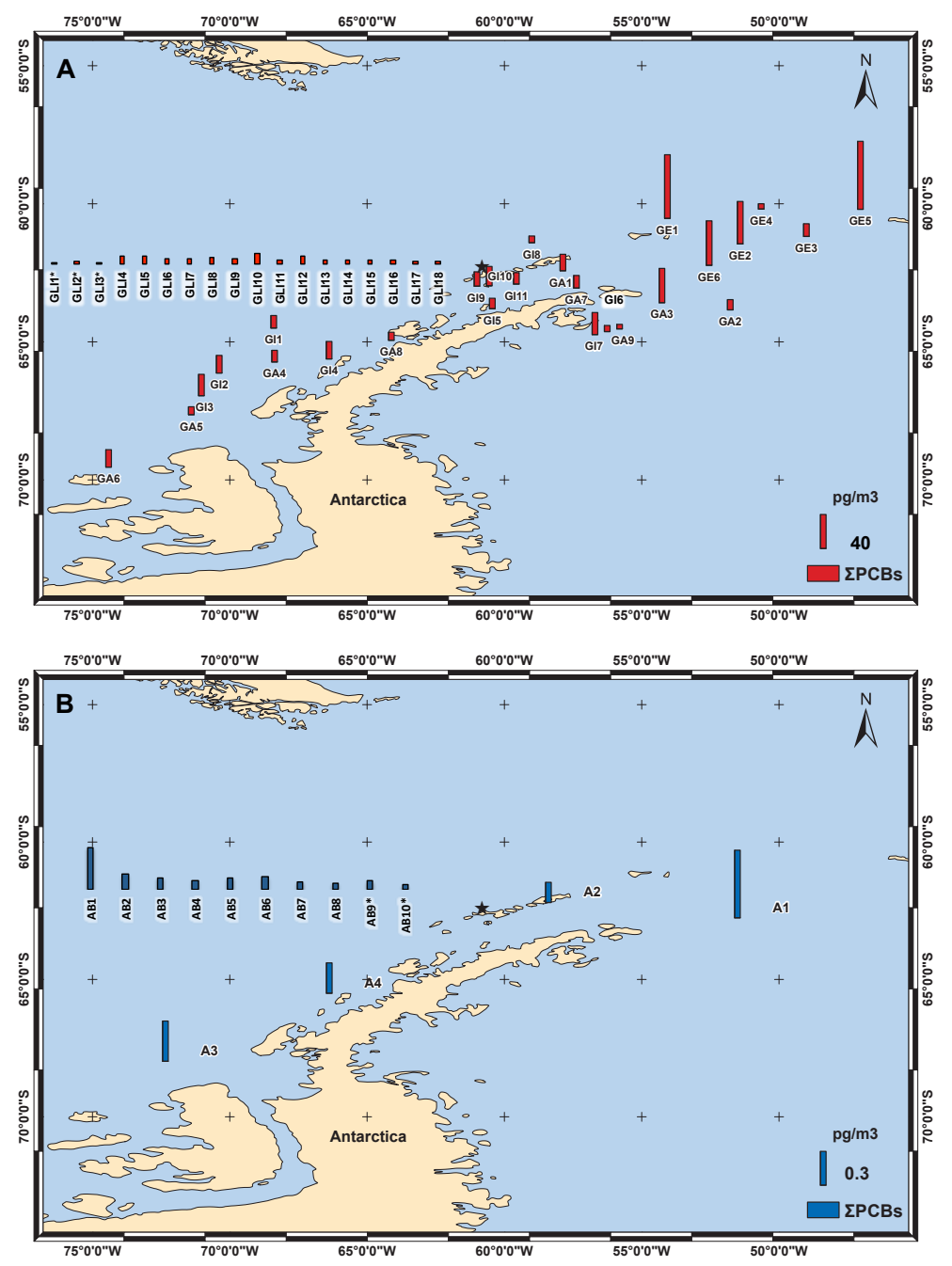

Fig. 2. Atmospheric occurrence of PCBs. Spatial distribution of gas (A) and aerosol (B) phase concentrations of polychlorinated biphenyls $\left(\Sigma_{25} \mathrm{PCBs}, \mathrm{pg} \mathrm{m}^{-3}\right)$ around the Antarctic peninsula in 2005 (ICEPOS), 2008 (ESSASI) and 2009 (ATOS II cruise and Livingston island samples). GI1-GI11 are samples taken during the ICEPOS cruise (2005), GE1-GE6 are samples taken during the ESSASI cruise (2008), GA1-GA9 are samples taken during the ATOS II cruise, and GLI1-GL18 are samples in Livingston island (* indicate the samples taken at Polish beach). A1-A4 are aerosol phase samples taken during ATOS II cruise and AB1-AB10 are samples taken at Linvingston island (* indicate aerosol phase samples taken at Polish beach).

surface water contaminants lowering their concentrations in the photic zone (Galbán-Malagón et al., 2013a). The influence of the biological pump on air-water dis-equilibrium is evidenced by plotting $\log f_{\mathrm{W}} f_{\mathrm{A}}^{-1}$ versus the temperature corrected octanol-water partition constant $\left(\log K_{\mathrm{OW}}\right)$, showing a lower value of $f_{\mathrm{W}} f_{\mathrm{A}}^{-1}$ for the more hydrophobic congeners ( $p<0.05)$ (Fig. 4b and Figs. S6 and S7 in Annex IV). This trend is consistent with the role of settling organic carbon lowering the dissolved phase concentrations for the more hydrophobic congeners, thus increasing the air-water fugacity gradients, pointing out the important role of phytoplankton as one of the controlling factors in the biogeochemical cycling of PCBs in the highly productive Southern Ocean around the Antarctic Peninsula (Dachs et al., 2002; GalbánMalagón et al., 2013a).

$F_{\mathrm{AW}}$ for each sampling period and $\mathrm{PCB}$ congener are given in Table $\mathrm{S} 13$ in Annex IV. $F_{\mathrm{AW}}$ for $\Sigma_{25} \mathrm{PCBs}$ ranged from -0.32 to $-7.67 \mathrm{ng} \mathrm{m}^{-2} \mathrm{~d}^{-1}$ and from -0.89 to $-7.01 \mathrm{ng} \mathrm{m}^{-2} \mathrm{~d}^{-1}$ during the ESSASI and ATOS II cruises, respectively. Figure 5a shows $F_{\mathrm{AW}}$ for each PCB congener and no significant differences with latitude were observed. Figure $5 \mathrm{~b}$ shows the average diffusive fluxes for individual PCB congeners. Even though the fugacity gradient is higher for the more hydrophobic congeners (Fig. $4 \mathrm{~b}$ ), $F_{\mathrm{AW}}$ do not significantly increases for the more chlorinated congeners because the abundances of the less chlorinated congeners is 

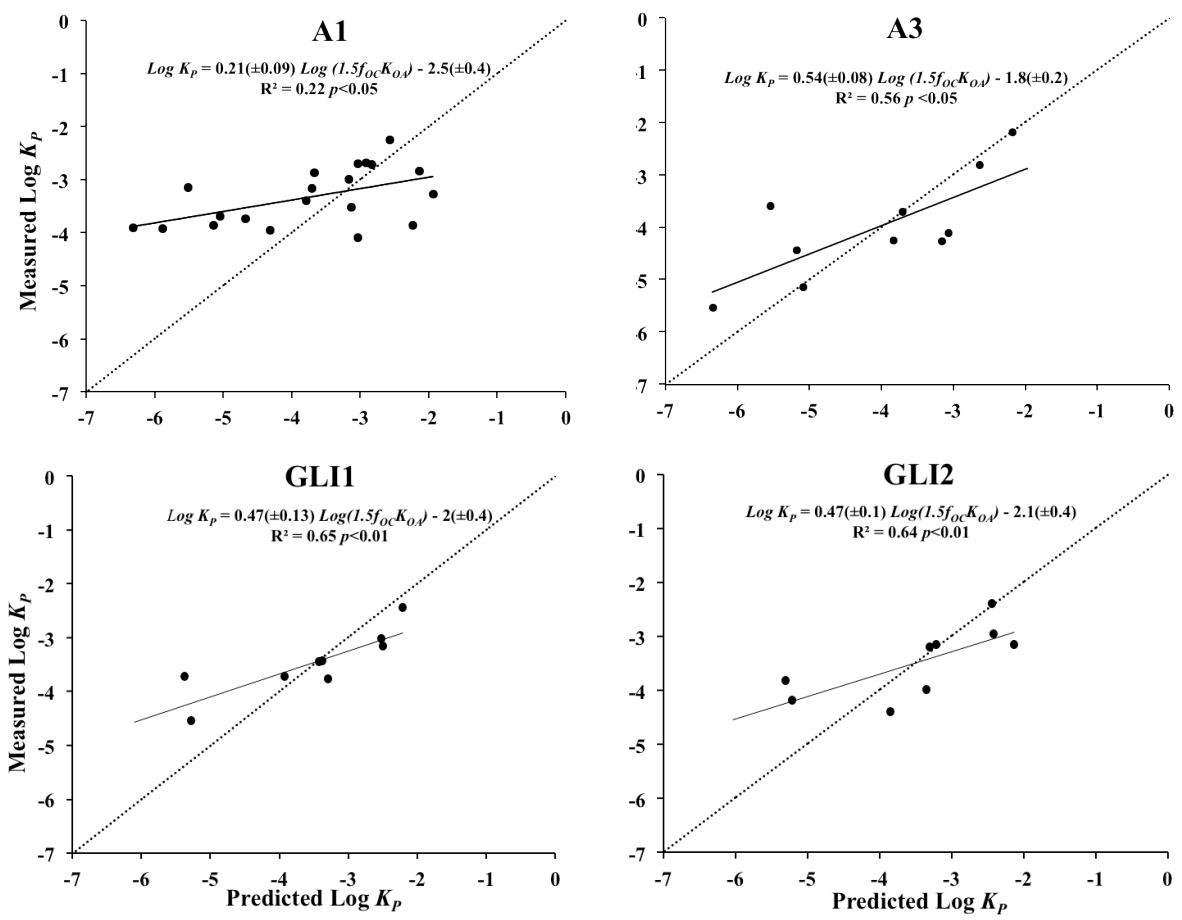

Fig. 3. Gas-particle partition of PCBs. Measured versus predicted particle-gas partition coefficients (Log $\left.K_{\mathrm{P}}\right)$ estimated for samples taken over the Southern Ocean (samples A1 and A3 in upper panels) and at Livingston island (samples GLI1 and GLI2 in lower panels).

higher in the gas phase, and $k_{\mathrm{AW}}$ is higher for lighter congeners.

Dry deposition fluxes for $\Sigma_{25} \mathrm{PCBs}$ ranged from -0.05 to $-0.2 \mathrm{ng} \mathrm{m}^{-2} \mathrm{~d}^{-1}$, and from -0.01 to $-0.1 \mathrm{ng} \mathrm{m}^{-2} \mathrm{~d}^{-1}$ in the Southern Ocean (Weddell Sea, Bransfield Strait, Bellingshausen Sea) and in Livingston Island, respectively. These dry deposition fluxes are from 9 to 500 times lower than airwater diffusive fluxes. In addition, the dry deposition fluxes calculated here for the Southern Ocean are also one to two orders of magnitude lower than the dry deposition fluxes estimated for the Arctic atmosphere (Galbán-Malagón et al., 2012). As discussed above, the measured gas-particle partitioning is consistent with the model predictions. Thus, the low dry deposition fluxes are solely due to the very low concentrations of PCBs in the aerosol phase, as a consequence of the low amounts of aerosol organic carbon in the atmosphere.

To better understand the fate of PCBs once they are deposited to seawater, it could be useful to compare these atmospheric deposition fluxes with the sediment accumulation fluxes of PCBs reported recently for the Bellingshausen Sea (Zhang et al., 2013). The ratio of air-water diffusive exchange of the ICES PCB congeners measured here to the sediment accumulation fluxes for the four sites reported by Zhang et al. (2013) are 9, 12, 14 and 1800 (dimensionless). Therefore, atmospheric deposition of PCBs to the Bellingshausen Sea is from one to three orders of magnitude higher than the accumulation in sediment. Conversely, the dry deposition fluxes of PCBs in the Bellingshausen Sea are up to 500 times lower than the diffusive fluxes (Tables S13 and S14). Thus, dry deposition of PCBs is between 16 times lower to similar magnitude than sediment accumulation fluxes. Once PCBs are deposited to the sea, there is dynamic seawaterparticle partitioning due to the high amounts and dynamics of organic matter in the photic zone. The biological pump is likely to be the major removal process of PCBs from surface waters as showed by the trend depicted in Fig. 4b, and by the decrease of PCB concentrations in phytoplankton at high biomass (Galbán-Malagón et al., 2013). Once in the mesopelagic zone, an important fraction of organic matter is remineralized driving the re-dissolution of PCBs in deep waters. In addition, remineralization of organic matter and partitioning to the dissolved phase can also occur at the sedimentwater interface. Therefore, a small amount of PCBs that enter the Southern Ocean will be accumulated in the sediments.

\subsection{Temperature dependence of gas phase concentrations}

Higher temperatures favour the displacement of the air-water, air-snow and air-soil partitioning towards the atmospheric side, thus inducing higher gas phase concentrations of POPs. Recently, higher gas phase concentrations of PCBs for the warmer periods have been described in the atmosphere at Livingston Island, consistent with the measured volatilization of PCBs from soils and snow (Cabrerizo et al., 2013). Similarly, hexaclorocyclohexanes, (HCHs) also show higher 

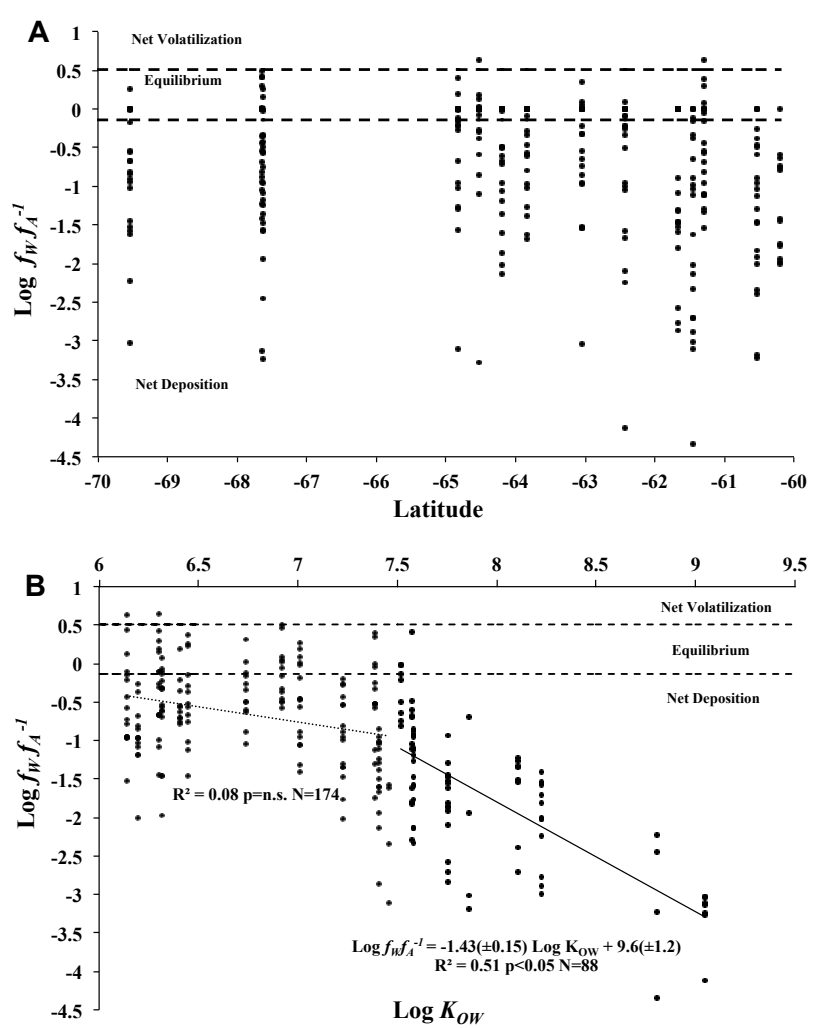

Fig. 4. Air-water dis-equilibrium of PCBs. Estimated congener specific air/water fugacity ratios $\left(\log f_{\mathrm{W}} / f_{\mathrm{A}}\right)$ calculated for the ESSASI and ATOS II cruises versus latitude (A), and versus the temperature corrected octanol water partition coefficient, Log $K_{\mathrm{OW}}$ (B).

concentrations at higher temperatures in the Antarctic atmosphere (Kang et al., 2012; Galbán-Malagón et al., 2013b). Other studies carried out in the Arctic have also shown that volatilization from seasonal snowpack is enhanced during high wind speed events, affecting the concentrations in the gas phase (Hallsall, 2004). Figure 6 (right panels) shows the significant correlation of gas phase concentrations of PCBs with air temperature at Pico Radio Hill site (data from Cabrerizo et al., 2013). Conversely, over the Southern Ocean, gas phase concentrations of PCBs are not correlated with temperature (Fig. 6, left panels). The absence of this relationship over the Southern Ocean agrees with previous results from Polar Regions in the Arctic (Oehme et al., 1996; Stern et al., 1997; Galbán-Malagón et al., 2012) and in Antarctica (Kallenborn et al., 1998) for PCBs. The lack of temperature dependence of atmospheric concentrations is consistent with an important contribution of long-range atmospheric transport (Wania et al., 1998a). During transport, the atmospheric concentrations are modulated by dilution, and the net deposition to the ocean. Conversely, the temperature dependent gas phase concentrations dependency on temperature tends to occur when the surface contamination and/or temperature are
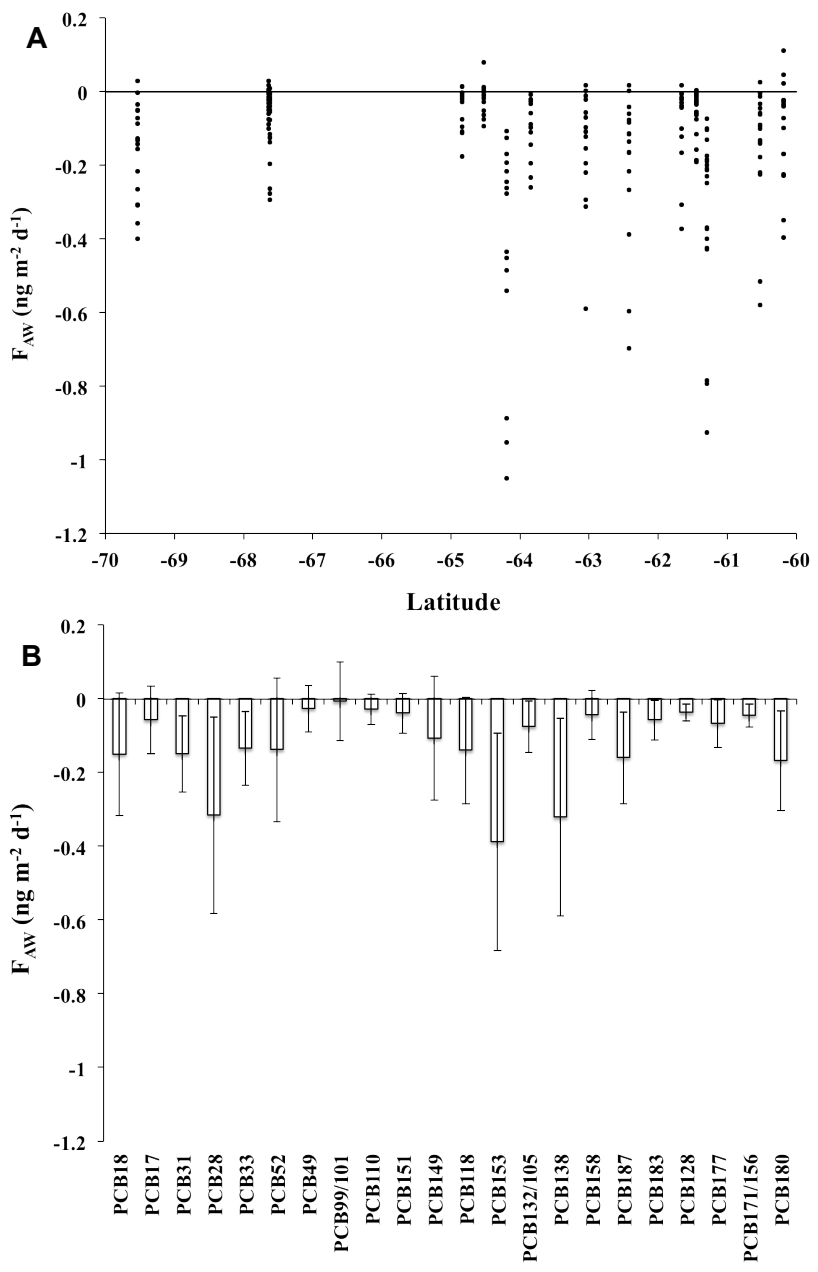

Fig. 5. Air-water exchange of PCBs. Net diffusive air-water exchange $\left(\mathrm{ng} \mathrm{m}^{-2} \mathrm{~d}^{-1}\right)$ fluxes during the ESSASI and ATOS II cruises versus latitude (A), and congener-specific diffusive fluxes for the Southern Ocean (B).

high (Wania et al., 1998b), supporting a volatilization, and thus an important contribution from local secondary sources as described for Livingston Island (Cabrerizo et al., 2013), especially for the less hydrophobic compounds.

\subsection{Factors affecting the atmospheric occurrence of PCBs in the Southern Ocean}

The $24 \mathrm{~h}$ air-mass back-trajectories for the air (gas and aerosol phase) samples showed three main origins (Fig. S3) (i) oceanic air masses from the west following the Antarctic circumpolar water current (ACC), (ii) air masses from the Weddell Sea (WS), and (iii) air mass that had "touched" the Antarctic continent or islands (AntC) during the previous $24 \mathrm{~h}$. There are no significant differences between the PCB concentrations measured in air samples influenced by the three characteristic air masses (Fig. S7 in Annex IV). This observation is consistent with the trends observed during the 


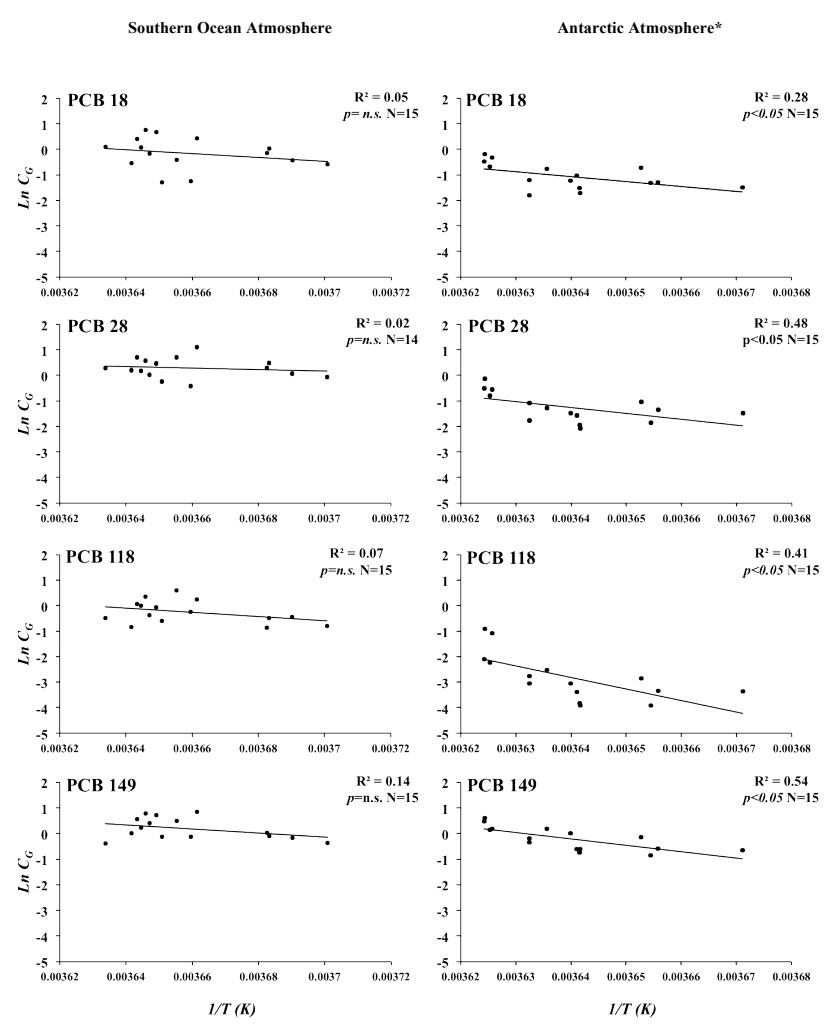

Fig. 6. Temperature dependence of atmospheric concentrations of PCBs. Natural logarithm of atmospheric gas phase concentrations concentration of PCBs $\left(\mathrm{Ln} C_{\mathrm{G}}, \mathrm{pg} \mathrm{m}^{-3}\right)$ versus inverse of air temperature $\left(1 / T, \mathrm{~K}^{-1}\right)$ in the Southern Ocean Atmosphere (left panels) and in the Antarctic atmosphere at Livingston island (right panels). *Data taken from Cabrerizo et al. (2013).

same cruises for perfluorinated compounds (Del Vento et al., 2012) and hexachlorobenzene (Galbán-Malagón et al., 2013b). However, for compounds such as hexachlorocyclohexane (HCHs), which are degraded/sequestered faster during transport, there was a significant influence of the $\mathrm{AntC}$ air masses supporting higher levels of HCHs (Galbán-Malagón et al., 2013b).

The lack of differences among the PCB concentrations for the different air mass back trajectories is due to the large variability in gas phase concentrations associated with AntC and ACC air masses. Conversely, the mean and variability of gas-phase concentrations for the WS air masses are low and consistent with lower concentrations driven by the high primary productivity in the Weddell Sea sequestering atmospheric pollutants. The extremely large variability for events dominated by the AntC air masses, may suggest that the influence of secondary sources of PCBs on the Antarctic continent cannot be ruled out. However, the air mass analysis cannot provide the information on the relative influence of secondary sources because of the high air-to water diffusive fluxes, which modify the atmospheric concentrations during transport. There is as well, a large variability in gas-phase concentrations when the air-mass has a Southern Ocean origin (ACC), which may be driven by several factors such as concentrations upwind and a number of factors affecting the transport efficiency of PCBs over the ocean such as the diverse strength of the biological pump capturing atmospheric PCBs, different wind speeds, and other potential factors that cannot be evaluated here.

The atmospheric half-lives of PCBs over the Southern Ocean can be estimated using the atmospheric deposition fluxes reported above. The average atmospheric concentrations of PCBs 52 and 180 are 1.4 and $0.5 \mathrm{pg} \mathrm{m}^{-3}$. Assuming an atmospheric mixing layer height of $500 \mathrm{~m}$, the atmospheric inventory of PCBs 52 and 180 is 0.72 and $0.25 \mathrm{ng} \mathrm{m}^{-2}$, respectively. Their calculated atmospheric deposition flux is 0.14 and $0.17 \mathrm{ng} \mathrm{m}^{-2} \mathrm{~d}^{-1}$, respectively, as shown in Fig. 5b. The atmospheric e-folding time or time needed to decrease the concentration to $1 / \mathrm{e}$ of initial concentrations, is given by the ratio of the inventory and atmospheric flux. The e-folding times for PCB52 and PCB180 are 5.2 and 1.5 days, which are similar to those predicted in this region when considering the influence of the biological pump sequestering atmospheric PCBs (Jurado and Dachs, 2008). These values are also comparable with those determined over other productive oceanic regions (Galbán-Malagón et al., 2012). The half-lives, the time to half the initial concentrations, are shorter, and yield 3.8 and 1 days for PCB52 and PCB180, respectively. During the austral summer, when the warming of soil and snow induces volatilization of PCBs, especially the less hydrophobic compounds (Cabrerizo et al., 2013), there is a continuous cycling of PCBs from the continent to the ocean. However, once volatilized, lighter PCB congeners will have higher capacity for long-range atmospheric transport as they are sequestered by the biological pump to a lower degree.

\section{Conclusions}

The present study reported the largest dataset on the atmospheric occurrence of PCBs in the Southern Ocean surrounding the Antarctic Peninsula. Concentrations are low in comparison to other oceanic regions and the estimations of atmospheric deposition show a net flux from the atmosphere to the ocean. The large air-to-water disequilibrium for the more hydrophobic compounds is consistent with the role of the biological pump driving the sequestration of atmospheric PCBs in the region. The concentrations in the aerosol phase are extremely low due to the small concentrations of organic aerosol in the Antarctic atmosphere, and dry deposition accounts for a small fraction of the total deposition fluxes. Atmospheric concentrations are not correlated with temperature over the Southern Ocean, contrasting with the clear temperature dependence of gas phase PCB concentrations over land. These distinct trends suggest the major contribution of long-range atmospheric transport and local secondary 
sources for the marine and terrestrial atmosphere, respectively.

\section{Supplementary material related to this article is available online at http://www.atmos-chem-phys.net/13/ 12029/2013/acp-13-12029-2013-supplement.pdf.}

\begin{abstract}
Acknowledgements. The crew of R/V Hespérides and UTM-CSIC team are acknowledged for support during the ICEPOS, ESSASI and ATOS II, sampling cruise and C. Duarte and D. Gomis for their contribution as chief scientists of the ICEPOS and ESSASSI cruises. This work was funded by DEPANT, BIOAEROSOL and ATOS projects of the Spanish Ministry of Science and Innovation. Galbán-Malagón is grateful for a pre-doctoral fellowship provided by the Spanish Ministry of Science and Innovation.
\end{abstract}

Edited by: R. Ebinghaus

\section{References}

Baek, S.-Y., Choi, S.-D., and Chang, Y.-S.: Three-year atmospheric monitoring of organochlorine pesticides and polychlorinated biphenyls in Polar Regions and the South Pacific, Environ. Sci. Technol., 45, 4475-4482, 2011.

Bengtson Nash, S. M., Poulsen, A. H., Kawaguchi, S., Vetter, W., and Schlabach, M.: Persistent organohalogen contaminant burdens in Antarctic krill (Euphausia superba) from the Eastern Antarctic sector: A baseline study, Sci. Total Environ., 407, 304314, 2008.

Bengtson-Nash, S. M., Rintoul, S. R., Kawaguchi, S., Staniland, I., Hoff, J. V. D., Tierney, M., and Bossi, R.: Perfluorinated compounds in the Antarctic Region: Ocean circulation provides prolonged protection from distant sources, Environ. Pollut., 158, 2985-2991, 2010.

Bengtson-Nash, S. M.: Persistent organic pollutants in Antarctica: Current and future research priorities, J. Environ. Monitor., 13, 497-504, 2011.

Berrojalbiz, N., Dachs, J., Del Vento, S., Ojeda, M. J., Valle, M. C., Castro-Jiménez, J., Mariani, G., Wollgast, J., and Hanke, G.: Persistent organic pollutants in Mediterranean seawater and processes affecting their accumulation in plankton, Environ. Sci. Technol., 45, 4315-4322, 2011.

Bidleman, T. F.: Atmospheric processes. Environ. Sci. Technol., 22, 361-367, 1988.

Birch, M. E. and Cary, R. A.: Elemental carbon-based method for monitoring occupational exposures to particulate diesel exhaust, Aerosol Sci. Technol., 25, 221-241, 1996.

Bogdal, C., Scheringer, M., Abad, E., Abalos, M., van Bavel, B., Hagberg, J., and Fiedler, H.: Worldwide distribution of persistent organic pollutants in air, including results of air monitoring by passive air sampling in five continents. TRAC-Trend, Anal. Chem. 46, 251-161, doi:10.1016/j.trac.2012.05.011, 2012.

Boyd, P. W., Robinson, C., Savidge, G., and Williams, P. J.: Water column and sea-ice primary production during austral spring in the Bellingshausen sea, Deep-Sea Res. Pt. II, 42, 1177-1200, 1995.
Brault, E. K., Goebel, M. E., Geisz, H. N., Canuel, E. A., and Dickhut, R. M.: Inter-annual variation of persistent organic pollutants (POPs) concentrations in an Antarctic top predator, Environ. Sci. Technol., 47, 12744-12752, doi:10.1021/es403577f, 2013.

Breivik, K., Alcock, R., Li, Y., Bailey, R. E., Fiedler, H., and Pacyna, J. M.: Primary sources of selected POPs: Regional and global scale emission inventories, Environ. Pollut., 128, 3-16, doi:10.1016/j.envpol.2003.08.031, 2004.

Cabrerizo, A., Dachs, J., Barceló, D., and Jones, K. C.: Influence of organic matter content and human activities on the occurrence of organic pollutants in Antarctic soils, lichens, grass, and mosses, Environ. Sci. Technol., 46, 1396-1405, 2012.

Cabrerizo, A., Dachs, J., Barceló, D., and Jones, K. C.: Climatic and biogeochemical controls on the remobilization and reservoirs of persistent organic pollutants in antarctica, Environ. Sci. Technol., 47, 4299-4306, 2013.

Dachs, J., Eisenreich, S. J., Baker, J. E., Ko, F.-C., and Jeremiason, J. D.: Coupling of phytoplankton uptake and air-water exchange of persistent organic pollutants, Environ. Sci. Technol., 33, 3653-3660, 1999.

Dachs, J., Eisenreich, S. J., and Hoff, R. M.: Influence of eutrophication on air-water exchange, vertical fluxes, and phytoplankton concentrations of persistent organic pollutants, Environ. Sci. Technol., 34, 1095-1102, 2000.

Dachs, J., Lohmann, R., Ockenden, W. A., Méjanelle, L., Eisenreich, S. J., and Jones, K. C.: Oceanic biogeochemical controls on global dynamics of persistent organic pollutants, Environ. Sci. Technol., 36, 4229-4237, 2002.

Draxler, R. R. and Rolph, G. D.: HYSPLIT (HYbrid Single-Particle Lagrangian Integrated Trajectory) Model access via NOAA ARL READY, NOAA Air Resources Laboratory: http://ready.arl.noaa. gov/HYSPLIT.php (last access: 1 June 2013), 2011.

Finizio, A., Mackay, D., Bidleman, T., and Harner, T.: Octanol-air partition coefficient as a predictor of partitioning of semi-volatile organic chemicals to aerosols, Atmos. Environ., 31, 2289-2296, 1997.

Fuoco, R., Colombini, M. P., Ceccarini, A., and Abete, C.: Polychlorobiphenyls in Antarctica, Microchem. J., 54, 384-390, 1996.

Galbán-Malagón, C., Berrojalbiz, N., Ojeda, M. J., and Dachs, J.: The oceanic biological pump modulates the atmospheric transport of persistent organic pollutants to the Arctic, Nat. Comm., 3, 862, doi:10.1038/ncomms1858, 2012.

Galbán-Malagón, C. J., Del Vento, S., Berrojalbiz, N., Ojeda, M. J., and Dachs, J.: Polychlorinated biphenyls, hexachlorocyclohexanes and hexachlorobenzene in seawater and phytoplankton from the Southern Ocean (Weddell, South Scotia, and Bellingshausen seas), Environ. Sci. Technol., 47, 5578-5587, 2013 a.

Galbán-Malagón, C. J., Cabrerizo, A., Caballero, G., and Dachs, J.: Atmospheric occurrence and deposition of hexachlorobenzene and hexachlorocyclohexanes in the Southern Ocean and Antarctic peninsula, Atmos. Environ., 80, 41-49, $2013 \mathrm{~b}$.

Gambaro, A., Manodori, L., Zangrando, R., Cincinelli, A., Capodaglio, G., and Cescon, P.: Atmospheric PCB concentrations at Terra Nova bay, Antarctica, Environ. Sci. Technol., 39, 9406-9411, 2005.

García-Flor, N., Guitart, C., Ábalos, M., Dachs, J., Bayona, J. M., and Albaigés, J: Enrichment of organochlorine contaminants in 
the sea surface microlayer: An organic carbon-driven process, Mar. Chem., 96, 331-345, 2005.

Gioia, R., Lohmann, R., Dachs, J., Temme, C., Lakaschus, S., Schulz-Bull, D., Hand, I., and Jones, K. C.: Polychlorinated biphenyls in air and water of the North Atlantic and Arctic Ocean (2008), J. Geophys. Res.-Atmos., 113, D19302, doi:10.1029/2007JD009750, 2008.

Gioia, R., Li, J., Schuster, J., Zhang, Y., Zhang, G., Li, X., Spiro, B., Bhatia, R. S., Dachs, J., and Jones, K. C.: Factors affecting the occurrence and transport of atmospheric organochlorines in the China Sea and the northern Indian and South East Atlantic Oceans, Environ. Sci. and Technol., 46, 10012-10021, 2012.

Grönlund, A., Nilsson, D., Koponen, I. K., Virkkula, A., and Hansson, M. E.: Aerosol dry deposition measured with eddycovariance technique at Wasa and Aboa, Dronning Maud land, Antarctica, Ann. Glaciol., 35, 355-361, 2002.

Halsall, C. J.: Investigating the occurrence of persistent organic pollutants (POPs) in the arctic: Their atmospheric behaviour and interaction with the seasonal snow pack, Environ. Pollut., 128, 163-175, 2004.

Harner, T. and Bidleman, T. F.: Measurement of octanol-air partition coefficients for polycyclic aromatic hydrocarbons and polychlorinated naphthalenes, J. Chem. Eng. Data, 43, 40-46, 1998a.

Harner, T. and Bidleman, T. F.: Octanol-air partition coefficient for describing particle/gas partitioning of aromatic compounds in urban air, Environ. Sci. Technol., 32, 1494-1502, 1998 b.

Iwata, H., Tanabe, S., Sakal, N., and Tatsukawa, R.: Distribution of persistent organochlorines in the oceanic air and surface seawater and the role of ocean on their global transport and fate, Environ. Sci. Technol., 27, 1080-1098, 1993.

Jones, K. C. and De Voogt, P.: Persistent organic pollutants (POPs): State of the science, Environ. Pollut., 100, 209-221, 1998.

Jurado, E. and Dachs, J.: Seasonality in the "grasshopping" and atmospheric residence times of persistent organic pollutants over the oceans, Geophys. Res. Lett., 35, L17805, doi:10.1029/2008GL034698, 2008.

Jurado, E., Jaward, F. M., Lohmann, R., Jones, K. C., Simó, R., and Dachs, J.: Atmospheric dry deposition of persistent organic pollutants to the Atlantic and inferences for the global oceans, Environ. Sci. Technol., 38, 5505-5513, 2004.

Kallenborn, R., Oehme, M., Wynn-Williams, D. D., Schlabach, M., and Harris, J.: Ambient air levels and atmospheric long-range transport of persistent organochlorines to Signy island, Antarctica, Sci. Total. Environ., 220, 167-180, 1998.

Kallenborn, R., Breivik, K., Eckhardt, S., Lunder, C. R., Manø, S., Schlabach, M., and Stohl, A.: Long-term monitoring of persistent organic pollutants (POPs) at the Norwegian Troll station in Dronning Maud Land, Antarctica, Atmos. Chem. Phys., 13, 6983-6992, doi:10.5194/acp-13-6983-2013, 2013.

Kang, J.-H, Son, M.-H., Hur, S.-D., Hong, S., Motoyama, H., Fukui, K., and Chang, Y.-S.: Deposition of organochlorine pesticides into the surface snow of East Antarctica, Sci. Total. Environ., 433, 290-295, 2012.

Larsson, P., Jarnmark, C., and Sodergren, A.: PCBs and chlorinated pesticides in the atmosphere and aquatic organisms of Ross island, Antarctica, Mar. Pollut. Bull., 25, 281-287, 1992.

Li, Y., Geng, D., Liu, F., Wang, T., Wang, P., Zhang, Q., and Jiang, G.: Study of PCBs and PBDEs in King George island, Antarctica, using PUF passive air sampling, Atmos. Environ., 51, 140-145, 2012.

Lohmann, R., Breivik, K., Dachs, J., and Muir, D.: Global fate of POPs: Current and future research directions, Environ. Pollut., 150, 150-165. 2007.

Ma, J., Hung, H., Tian, C., and Kallenborn, R.: Revolatilization of persistent organic pollutants in the Arctic induced by climate change, Nature Clim. Change, 1, 255-260, doi:10.1038/nclimate1167, 2011.

Mandalakis, M. and Stephanou, E. G. Atmospheric concentration characteristics and gas-particle partitioning of PCBs in a rural area of Eastern Germana, Environ. Pollut., 147, 211-221, 2007.

Meijer, S. N., Dachs, J., Fernandez, P., Camarero, L., Catalan, J., Del Vento, S., Van Droodge, B., Jurado, E., and Grimalt, J. O.: Modelling the dynamic air-water-sediment coupled fluxes and occurrence of polychlorinated biphenyls in a high altitude lake, Environ. Pollut., 140, 546-560, 2006.

Montone, R. C., Taniguchi, S., and Weber, R. R.: PCBs in the atmosphere of King George island, Antarctica, Sci. Total. Environ., 308, 167-173, 2003.

Montone, R. C., Taniguchi, S., Boian, C., and Weber, R. R.: PCBs and chlorinated pesticides (DDTs, $\mathrm{HCHs}$ and $\mathrm{HCB}$ ) in the atmosphere of the Southwest Atlantic and Antarctic Oceans, Mar. Pollut. Bull., 50, 778-786, 2005.

Nizzetto, L., MacLeod, M., Borgå, K., Cabrerizo, A., Dachs, J., Guardo, A. D., Ghirardello, D., Hansen, K. M., Jarvis, A., Lindroth, A., Ludwig, B., Monteith, D., Perlinger, J. A., Scheringer, M., Schwendenmann, L., Semple, K. T., Wick, L. Y., Zhang, G., and Jones, K. C.: Past, present, and future controls on levels of persistent organic pollutants in the global environment, Environ. Sci. Technol., 44, 6526-6531, 2010.

Nizzetto, L., Gioia, R., Li, J., Borgå, K., Pomati, F., Bettinetti, R., Dachs, J., and Jones, K. C.: Biological pump control of the fate and distribution of hydrophobic organic pollutants in water and plankton, Environ. Sci. Technol., 46, 3204-3211, 2012.

Ockenden, W. A., Lohmann, R., Shears, J. R., and Jones, K. C.: The significance of PCBs in the atmosphere of the Southern Hemisphere, Environ. Sci. Pollut. R., 8, 189-194, 2001.

Oehme, M.: Seasonal changes and relations between levels of organochlorines in Arctic ambient air: First results of an all-yearround monitoring program at Ny-Alesund, Svalbard, Norway, Environ. Sci. Technol., 30, 2294-2304, 1996.

Radonić, J., Miloradov, M. V., Sekulić, M. T., Kiursk, J., Djogo, M., and Milovanović, D.: The octanol-air partition coefficient, $K_{\mathrm{OA}}$, as a predictor of gas-particle partitioning of polycyclic aromatic hydrocarbons and polychlorinated biphenyls at industrial and urban sites, J. Serb. Chem. Soc., 76, 447-458, 2011.

Rintoul, S. R.: Southern Ocean currents and climate, Pap. Proc. R. Soc. Tasman, 133, 41-50, 2000.

Rowe, A. A., Totten, L. A., Xie, M., Fikslin, T. J., and Eisenreich, S. J.: Air-water exchange of polychlorinated biphenyls in the Delaware River, Environ. Sci. Technol., 41, 1152-1158, 2007.

Scheringer, M.: Characterisation of the environmental distribution behavior of organic chemicals by means of persistence and spatial range, Environ. Sci. Technol., 31, 2891-2897, 1997.

Stern, G. A., Halsall, C. J., Barrie, L. A., Muir, D. C. G., Fellin, P., Rosenberg, B., Rovinsky, F. Y. A., Kononov, E. Y. A., and Pastuhov, B.: Polychlorinated biphenyls in Arctic air. 1. temporal 
and spatial trends: 1992-1994, Environ. Sci. Technol., 31, 36193628, 1997.

Tanabe, S., Hidaka, H., and Tatsukawa, R.: PCBS and chlorinated hydrocarbon pesticides in Antarctic atmosphere and hydrosphere, Chemosphere, 12, 277-288, 1983.

Totten, L. A., Brunciak, P. A., Gigliotti, C. L., Dachs, J., Glenn IV, T. R., Nelson, E. D., and Eisenreich, S. J.: Dynamic air-water exchange of polychlorinated biphenyls in the new york-new jersey harbor estuary, Environ. Sci. Technol., 35, 3834-3840, 2001.

Tréguer, P. and Jacques, G.: Dynamics of nutrients and phytoplankton, and fluxes of carbon, nitrogen and silicon in the antarctic ocean, Polar Biol., 12, 149-162, 1992.

Wania, F. and Mackay, D.: Tracking the distribution of persistent organic pollutants, Environ. Sci. Technol., 30, 390A-397A, 1996.
Wania, F., Haugen, J. E., Lei, Y. D., and Mackay, D.: Temperature Dependence of Atmospheric Concentrations of Semivolatile Organic Compounds, Environ. Sci. Technol., 32, 1013-1021, 1998a.

Wania, F., Axelman, J., and Broman, D.: A review of processes involved in the exchange of persistent organic pollutants across the air-sea interface, Environ. Pollut., 102, 3-23, 1998b.

Zhang, L., Dickhut, R., Demaster, D., Pohl, K., and Lohmann, R.: Organochlorine pollutants in Western Antarctic peninsula sediments and benthic deposit feeders, Environ. Sci. Technol., 47, 5643-5651, 2013. 